\title{
PERDAGANGAN SATWA LIAR DI PASAR TRADISIONAL DAN PASAR MODERN DI SULAWESI UTARA
}

\author{
(Wildlife trade in traditional markets and modern markets in North Sulawesi)
}

\author{
Liana', Witno $^{2}$ \\ Fakultas Kehutanan, Universitas Andi Djemma Kota Palopo \\ Email: $\underline{\text { lianabhr@gmail.com }}$
}

\begin{abstract}
The trade-in wild animals for consumption in North Sulawesi Province spread to traditional markets in several districts, including the Tomohon Faith Market, a tourist destination for unique domestic and foreign meat markets. Even the trade in wild animal meat has now entered modern markets or supermarkets in Manado. This development, of course, threatens the preservation of biodiversity, especially endemic species. This study aims to determine the types of wildlife traded in North Sulawesi in traditional and modern markets, compare the price of wild animal meat in conventional and contemporary markets in North Sulawesi, and determine the conservation status of traded wildlife species. The study results found eight wild animals sold in traditional markets: Sus scrofa, Canis lufus, Pteropus electo, Acerodon celebencis, Felis catus, Python reticulatus Varanus Salvator, and Rattus novegicus. There are five types of which are found sold in modern markets or supermarkets in Manado City. The price of wild animal meat in traditional markets is the cheapest for Rattus novegicus Rp. 15,000/kg to the highest for Varanus Salvator Rp. 65,000/kg. Meanwhile, the price of wild animal meat in the Modern Market is up to 3 times higher than the traditional market price. Of the eight species of animals traded, two are included in the CITES Appendix II list, while the other six species are not protected.
\end{abstract}

Keywords: wildlife, traditional markets, trade wildlife

\begin{abstract}
ABSTRAK
Perdagangan satwa liar untuk kebutuhan konsumsi di Provinsi Sulawesi Utara menyebar di pasar-pasar tradisional pada beberapa kabupaten diantaranya Pasar Beriman Tomohon yang juga menjadi tujuan wisata pasar daging unik baik domestik maupun mancanegara. Bahkan perdagangan daging satwa liar saat ini sudah masuk ke Pasar-pasar modern atau supermarket yang terdapat di Kota Manado. Perkembangan ini tentu saja mengancam kelestarian keanekaragaman hayati terutama spesies endemik. Penelitian ini bertujuan untuk mengetahui jenis satwa liar yag diperdagangkan di Sulawesi Utara baik di Pasar tradisional maupun pasar modern, mengetahui perbandingan harga daging satwa liar di pasar-pasar tradisional dengan modern di wilayah Sulawesi Utara, serta mengetahui status konservasi jenis satwa liar yang diperdagangkan. Hasil penelitian menemukan 8 jenis satwa liar yang diperdagangkan di pasar tradisional yaitu Sus scrofa, Canis lufus, Pteropus electo, Acerodon celebencis, Felis catus, Phyton reticulatus, Varanus salvator dan Rattus novegicus. Terdapat 5 jenis diantaranya ditemukan dijual di Pasar modern atau supermarket di Kota Manado. Harga daging satwa liar di Pasar-pasat tradisional termurah daging Rattus

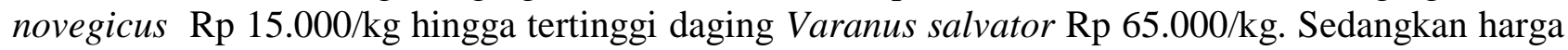
daging satwa liar di Pasar Modern lebih tinggi hingga 3 kali lipat dari harga Pasar tradisional. Dari 8 jenis satwa yang diperdagangkan terdapat 2 jenis yang masuk ke dalam daftar Appendiks II CITES sedangkan 6 jenis lainnya tidak dilindungi.
\end{abstract}

Kata Kunci: Satwa Liar, Pasar Tradisional, Perdagangan Satwa Liar 


\section{PENDAHULUAN}

Perdagangan satwa liar untuk konsumsi terjadi di berbagai negara di dunia. Di Afrika Perdagangan satwa liar untuk konsumsi terjadi selama berabad-abad lamanya, dan ini dianggap sebagai salah satu ancaman terpenting bagi satwa liar di daerah tropis (Guy C. dkk, 2005). Demikian halnya di Indonesia perdagangan satwa liar untuk konsumsi, seperti di Provinsi Sulawesi Utara perdagangan satwa liar tersebar di beberapa wilayah diantaranya di Kab.Minahasa dan Kota Manado (Mildenstein et al., 2013), hal yang sama juga terdapat di Provinsi Kalimantan Barat perdagangan satwa liar di Kota Pontianak dapat ditemukan baik dalam kondisi hidup maupun sebagai bahan pangan (Ignasius dkk, 2019).

Sulawesi Utara menjadi area dengan pasar daging satwa liar yang terbesar dan terbanyak di kawasan Asia Tenggara (Lee, 2005), Konsumsi daging satwa liar dianggap sebagai bagian dari budaya Sulawesi Utara (Saroyo, 2011), daging satwa liar dihidangkan dalam perayaan keagamaan (Sheherazade dan Tsang, 2015), pesta dan acara keluarga (Liana dkk, 2019). Disamping itu daging satwa liar dikonsumsi untuk bahan pangan penghasil protein pengganti daging serta beberapa satwa liar dipercaya berkhasiat untuk menyembuhkan penyakit (Liana dkk, 2019).

Bushmeat membuat beberapa wilayah di Sulawesi Utara terkenal, bahkan dijadikan sebagai salah satu daya tarik wisata. Satwa liar yang diperdagangkan antara lain kelelawar/paniki/kalong, tikus hutan, babi hutan, ular piton, yaki (monyet hitam Sulawesi), biawak, anjing, dan kucing. Bahkan satwa endemik Sulawesi seperti Paniki Yaki atau Acerodon celebencis dan Yaki diperdagangkan dengan bebas guna memenuhi kebutuhan konsumsi. Penjualan daging satwa liar akan meningkat di akhir pekan, penjualan di weekend (sabtu dan minggu) mencapai angka penjualan senin sampai jumat (Liana $\mathrm{dkk}, 2019$ ), demikian juga akan meningkat penjualan di hari besar keagamaan seperti natal dan paskah (Sheherazade dan Tsang, 2015).

Penjualan daging satwa liar ini tersebar di beberapa pasar tradisional dan pasar modern di Sulawesi Utara, yang paling terkenal dan jadi tujuan wisata baik domestik dan mancanegara yaitu Pasar tradisional Beriman di Tomohon. Terdapat juga di Pasar Langowan dan Kawangkoan di Kab. Minahasa, Pasar Bersehati dan Pasar Karombassan di Kota Manado. Selain pasar tradisional juga tersebar di pasar modern yaitu supermarket-supermarket di Kota Manado. Daging satwa liar ini dipasok dari berbagai daerah di Sulawesi antara lain dari Provinsi Sulawesi Selatan, Sulawesi Tengah, dan Gorontalo. Jaringan perdagangan satwa liar ini mulai dari pemburu, pengumpul hingga ke pedagang di pasar-pasar tradisional dan supermarket (Liana, 2019) seperti kelelawar. Tetapi ada juga satwa yang diambil dari jalanan, seperti anjing dan kucing. Sehingga harga satwa liar ini akan beragam berdasarkan harga dari supplier/pengumpul, berdasarkan penelitian Liana dkk untuk perdagangan satwa kelelawar yang menjadi penentu harga adalah pengumpul.

Penyebaran penjualan daging satwa liar untuk kebutuhan konsumsi menjadi ancaman bagi kelestarian keanekaragaman hayati, bahkan kombinasi antara rusaknya habitat dan eksploitasi satwa untuk perdagangan membuat satwa endemik tidak mampu bertahan hidup. Hal yang sama diungkapkan Gono S (2007) bahwa Penurunan populasi terjadi oleh karena tiga faktor, yaitu rusaknya/turunnya kualitas habitat, laju perburuan ( $k i l l)$ dan laju penjualan (product). Komoditas yang diperjual belikan seringkali turun kuantitasnya secepat turunnya populasi, dan aktifitas jual-beli baru terhenti saat populasi telah benar-benar diambang kritis.

Perdagangan daging satwa liar untuk kebutuhan konsumsi telah menyebar dari tingkat lokal ke tingkat provinsi, dan dari pasar tradisional ke pasar modern/supermarket. Tidak adanya regulasi menyebabkan perdagangan daging satwa liar ini menjadi peluang ekonomi potensial bagi pedagang. Perdagangan satwa liar untuk konsumsi ini akan memicu perburuan satwa yang tidak berkelanjutan yang akhirnya akan mengancam kepunahan satwa, serta meningkatkan risiko kehilangan jasa ekosistem dari satwa-satwa ini. Oleh karena itu penting dilakukan penelitian ini untuk mengetahui jenis satwa liar yang diperdagangkan baik di Pasar 
tradisional maupun pasar modern dan mengetahui status konservasi satwa liar tersebut. Selanjutnya penelitian ini untuk membandingkan harga daging satwa liar yang terdapat di pasar tradisional dengan pasar modern/supermarket. Penelitian ini diharapkan dapat memberikan informasi kepada stakeholder terkait guna mencegah perdagangan satwa tanpa memperhatikan kelestarian satwa.

\section{METODE PENELITIAN}

Penelitian dilakukan di Pasar Langowan, Pasar Kawangkoan, Pasar Beriman Tomohon yang terdapat di Kab. Minahasa, Pasar Karombassan dan pasar modern yang ada di Kota Manado. Metode penelitian dengan menggunakan metode survey. Tekhnik pengumpulan data dengan tekhnik wawancara. Analisis data dengan analisis deskriptif kualitatif.

\section{HASIL DAN PEMBAHASAN}

Hasil penelitian dari keempat pasar tradisional yaitu Pasar Langowan, Kawangkoan, Beriman dan Karombassan terdapat 8 jenis daging satwa liar yang diperdagangkan, sedangkan keempat pasar modern/supermarket yaitu Multimart Mega Mas, Multimart Zero Point, Transmart Carrefour dan Freshmart terdapat 5 jenis satwa liar yang diperdagangkan. Diperoleh data bahwa hanya daging kelelawar (Pteropus ecelcto/Acerodon celebencis) yang dijual di keempat pasar tradisional dan keempat pasar modern/supermarket. Hal ini menunjukkan bahwa daging kelelawar menjadi salah satu daging satwa liar yang digemari masyarakat baik dari rasa dan harganya yang terjangkau, penelitian Liana dkk (2019) memperoleh data bahwa daging kelelawar untuk konsumsi di Sulawesi Utara mencapai 569.515 ekor per tahun atau setara dengan 189 ton per tahun.

Umumnya harga daging satwa liar di pasar tradisional lebih murah dibandingkan dengan harga daging satwa liar di pasar modern/supermarket, kecuali harga daging Ular phyton (Python reticulatus) harganya lebih mahal di pasar tradisional yaitu $50.000 / \mathrm{kg}$ dibanding pasar modern yaitu 30.000/kg. Perbedaan harga ini dipengaruhi oleh supply daging ular tersebut baik ke pasar tradisional maupun ke pasar modern, dimana harga daging ular tersebut ditentukan oleh supplier.

\section{Jenis Daging Satwa Liar yang Diperdagangkan di Pasar Tradisonal dan Pasar Modern}

Berdasarkan hasil penelitian dari keempat pasar yaitu Pasar Langowan, Kawangkoan, Beriman dan Karombassan diperoleh hasil bahwa jenis-jenis satwa liar yang diperdagangkan antara lain yaitu:

Tabel 1. Jenis satwa liar yang diperdagangkan di Pasar-pasar tradisional Sulawesi Utara

\begin{tabular}{|c|c|c|c|c|c|c|}
\hline \multirow{2}{*}{ No } & \multirow{2}{*}{ Nama Satwa } & \multirow{2}{*}{ Latin } & \multicolumn{4}{|c|}{ Pasar } \\
\hline & & & Langowan & Kawangkoan & Beriman & Karombassan \\
\hline 1 & Babi Hutan & Sus scrofa & $\sqrt{ }$ & $\sqrt{ }$ & $\sqrt{ }$ & $\sqrt{ }$ \\
\hline 2 & Anjing & Canis lufus & $\sqrt{ }$ & $\sqrt{ }$ & $\sqrt{ }$ & $\sqrt{ }$ \\
\hline 3 & $\begin{array}{l}\text { Kelelawar } \\
\text { hitam }\end{array}$ & Pteropus electo & $\sqrt{ }$ & $\sqrt{ }$ & $\sqrt{ }$ & $\sqrt{ }$ \\
\hline 4 & $\begin{array}{c}\text { Kelelawar } \\
\text { pirang/Paniki } \\
\text { Yaki }\end{array}$ & $\begin{array}{l}\text { Acerodon } \\
\text { celebencis }\end{array}$ & $\sqrt{ }$ & $\sqrt{ }$ & $\sqrt{ }$ & $\sqrt{ }$ \\
\hline 5 & Kucing & $\begin{array}{c}\text { Felis catus } \\
\text { Python }\end{array}$ & $\sqrt{ }$ & $\sqrt{ }$ & - & - \\
\hline 6 & Ular Phyton & $\begin{array}{l}\text { reticulatus } \\
\text { Varanus }\end{array}$ & $\sqrt{ }$ & $\sqrt{ }$ & $\sqrt{ }$ & $\sqrt{ }$ \\
\hline 7 & Biawak/Soa soa & $\begin{array}{c}\text { salvator } \\
\text { Rattus }\end{array}$ & $\sqrt{ }$ & $\sqrt{ }$ & $\sqrt{ }$ & $\sqrt{ }$ \\
\hline 8 & Tikus & norvegicus & $\sqrt{ }$ & $\sqrt{ }$ & $\sqrt{ }$ & $\sqrt{ }$ \\
\hline
\end{tabular}


Data pada Tabel 1 dapat dilihat bahwa ada 8 jenis satwa liar yang diperdagangkan di pasar-pasar yang tersebar di Sulawesi Utara. Mulai dari reptil hingga mamalia, adapun satwa tersebut yaitu Babi hutan, Anjing, Kelelawar hitam, Paniki Yaki, Kucing, Ular phyton, Biawak dan tikus. Untuk Pasar Langowan dan
Kawangkoan yang berada di Kab. Minahasa sama-sama menjual delapan jenis satwa tersebut, sedangkan Pasar Beriman di Kab. Minahasa dan Pasar Karombassan yang ada di Kota Manado hanya daging kucing yang tidak ditemui di kedua pasar tersebut.

Tabel 2. Jenis satwa liar yang diperdagangkan di Pasar Modern Kota Manado

\begin{tabular}{|c|c|c|c|c|c|c|}
\hline \multirow[b]{2}{*}{ No } & \multirow[b]{2}{*}{ Nama Satwa } & \multirow[b]{2}{*}{ Latin } & \multicolumn{4}{|c|}{ Pasar Modern/Supermarket } \\
\hline & & & $\begin{array}{l}\text { Multi Mart } \\
\text { Mega Mas }\end{array}$ & $\begin{array}{l}\text { Multimart } \\
\text { Zero } \\
\text { Point }\end{array}$ & $\begin{array}{l}\text { Transmart } \\
\text { Carrefour }\end{array}$ & Freshmart \\
\hline 1 & Babi Hutan & Sus scrofa & - & - & $\sqrt{ }$ & $\sqrt{ }$ \\
\hline 2 & Anjing & Canis lufus & $\sqrt{ }$ & $\sqrt{ }$ & - & - \\
\hline 3 & Kelelawar & $\begin{array}{l}\text { Pteropus } \\
\text { electo/Acerodon } \\
\text { celebencis }\end{array}$ & $\sqrt{ }$ & $\sqrt{ }$ & $\sqrt{ }$ & $\sqrt{ }$ \\
\hline 4 & Ular Phyton & Python reticulatus & - & - & - & $\sqrt{ }$ \\
\hline 5 & Tikus & Rattus norvegicus & $\sqrt{ }$ & $\sqrt{ }$ & - & - \\
\hline
\end{tabular}

Data pada Tabel 2 dapat dilihat bahwa hanya ada 5 jenis satwa yang diperdagangkan di Pasar modern yaitu supermarket-supermarket yang tersebar di Kota Manado yaitu Babi hutan, anjing, kelelawar, ular phyton dan tikus. Untuk kelelawar sulit untuk membedakan antara Acerodon celebencis dan Pteropus electo karena peneliti tidak melihat dari awal (masih bisa dibedakan spesies dari warna bulu), hal ini disebabkan daging kelelawar di supermarket sudah dalam kondisi siap jual dimana kondisi daging tanpa bulu.

Terdapat perbedaan jenis daging satwa liar yang diperdagangkan antara pasar tradisional dan pasar modern. Di Pasar modern atau supermarket yang tersebar di Kota Manado hanya terdapat 5 jenis daging satwa yang diperdagangkan, hal ini mengikuti permintaan pasar yang ada di Kota Manado. Kondisi daging satwa sama baik di Pasar tradisional maupun di Supermarket yaitu daging satwa sebelum dijual dibersihkan dari bulu dengan cara dibakar, sehingga tampilan daging satwa umumnya berwarna hitam. Untuk daging kelelawar sebelum dibakar untuk menghilangkan bulu terlebih dahulu dilepas sayapnya, hal ini untuk memudahkan dalam proses pembakarannya. Daging kelelawar dan tikus dijual dengan kondisi ditusuk dengan bambu, hal ini untuk memudahkan pada saat proses pembakaran. Sedangkan daging anjing dan kucing dijual dengan bentuk utuh hanya dibakar untuk menghilangkan bulunya. Sedangkan daging babi hutan, biawak, ular phyton sebelum dibakar terlebih dahulu dipotong-potong untuk memudahkan proses.

Perbedaan kemasan daging satwa yang dijual di pasar tradisional dengan pasar modern atau supermarket yaitu kalau di Pasar tradisional daging satwa hanya dipajang biasa dan untuk bungkusnya menggunakan kantong kresek biasa, sementara di pasar modern atau supermarket daging satwa liar dikemas menggunakan stereoform dan dibungkus dengan plastik makanan sehingga terlihat lebih rapi dan bersih, serta tidak ditemui bambu yang ada di daging kelelawar dan tikus.

Mengkonsumsi berbagai jenis daging satwa liar ini selain disukai karena rasanya juga dipercaya memberi khasiat. Ada beberapa daging yang paling sering dikonsumsi yaitu babi hutan, kelelawar, ular dan anjing. Untuk daging babi hutan dan anjing dipercaya masyarakat karena rasanya enak dan mengandung protein dan baik untuk kesehatan. Konsumsi daging kelelawar karena rasanya 
yang enak seperti daging ayam bahkan untuk jenis Acerodon celebencis dipercaya lebih enak karena ada rasa manis juga dipercaya mampu mengobati penyakit asma dan memberikan rasa hangat ketika mengkonsumsi daging kelelawar. Masyarakat percaya daging kelelawar bersih karena hanya makan daun, bahkan daging kelelawar disantap tanpa mengeluarkan isi perutnya (Liana dkk, 2019). Konsumsi daging ular, empedu bahkan darah dipercaya memberi banyak khasiat diantaranya menyembuhkan alergi dan penyakit kulit, hal yang sama dikemukakan Kartikasari (2008) selain untuk penyakit kulit masyarakat Jawa Tengah mengkonsumsi daging ular untuk mengobati liver, stroke dan sakit pernafasan. Sedangkan untuk masyarakat bogor selain untuk penyakit kulit konsumsi daging ular dipercaya menetralkan racun dalam tubuh dan menambah stamina (Situngkir, 2009).

Daging biawak juga banyak dikonsumsi setelah daging ular, tetapi tidak ada alasan yang khusus dari masyarakat untuk mengkonsumsi daging ini. Kebiasaan mengkonsumsi daging biawak juga dilakukan oleh masyarakat Pontianak untuk mengobati penyakit kulit, dan empedu biawak dipercaya dapat mengobati penyakit flu, dan gigitan hewan berbisa seperti ular, kalajengking (Ignasius dkk, 2019).
Taogan S (2020) menyatakan bahwa mengkonsumsi daging satwa liar di Sulawesi Utara tidak terlepas dari budaya yang turun menurun, bahkan sedikit yang menyantap daging satwa liar karena obat. Hal yang sama yang dinyatakan oleh Liana dkk (2019) menyatakan bahwa budaya bukan lagi satusatunya alasan masyarakat mengkonsumsi daging satwa liar, tetapi karena rasa daging satwa liar yang enak dan digemari masyarakat.

Fenomena penjualan satwa liar yang meluas dari pasar tradisional sampai ke supermarket di kota besar menandakan bahwa penikmat daging satwa liar telah masuk ke seluruh lapisan masyarakat, masyarakat dengan golongan ekonomi menengah ke bawah sampai menengah ke atas, semua kalangan umur mulai dari anak-anak sampai dewasa menikmati daging satwa liar. Bahkan saat ini telah ditemukan penjualan daging satwa liar melalui aplikasi digital, sehingga jangkauan penjualan daging satwa liar bisa lebih luas.

\section{Harga Daging Satwa Liar di Pasar Tradisonal dan Supermarket}

Adapun daftar harga daging satwa liar yang dijual di pasar tradisional dan supermarket disajikan pada Tabel 3 berikut ini:

Tabel 3. Perbandingan Harga daging satwa liar di Pasar Tradisional dengan Supermarket

\begin{tabular}{|c|c|c|c|c|}
\hline \multirow{2}{*}{ No } & \multirow{2}{*}{ Nama Satwa } & \multirow{2}{*}{ Latin } & \multicolumn{2}{|c|}{ Harga per kg } \\
\hline & & & Pasar Tradisional & Supermarket \\
\hline 1 & Babi Hutan & Sus scrofa & 35.000 & $36.000-45.000$ \\
\hline 2 & Anjing & Canis lufus & - & 45.000 \\
\hline 3 & Kelelawar & $\begin{array}{l}\text { Pteropus } \\
\text { electo/Acerodon } \\
\text { celebencis }\end{array}$ & $25.000-30.000$ & $79.800-100.000$ \\
\hline 4 & Kucing & Felis catus & - & - \\
\hline 5 & Ular Phyton & Python reticulatus & 50.000 & 30.000 \\
\hline 6 & Biawak/Soa soa & Varanus salvator & 65.000 & - \\
\hline 7 & Tikus & Rattus norvegicus & 15.000 & 30.000 \\
\hline
\end{tabular}

Data pada Tabel 3 memperlihatkan perbedaan harga daging satwa liar antara pasar tradisional dan supermarket, harga daging satwa liar di supermarket cenderung lebih tinggi dari pasar tradisional bahkan harga daging kelelawar 3 kali lipat lebih mahal 32 harganya dibanding pasar tradisional. Pasar modern adalah pasar yang dikelola dengan manajemen yang modern, umumnya terdapat di perkotaan, sebagai penyedia barang dan jasa dengan mutu dan pelayanan yang baik kepada konsumen, barang yang dijual mempunyai 
Volume 3 Nomor 1 Juli 2021:28-34

kualitas yang relatif lebih terjamin dan dari segi harga, pasar modern memiliki label harga yang pasti (Sinaga, 2006). Pelayanan jasa tersebut membuat harga di pasar modern cenderung lebih tinggi.

\section{Status Konservasi Satwa}

Sembilan jenis satwa liar yang diperdagangkan terdapat satu jenis satwa yang merupakan endemik sulawesi yaitu kelelawar pirang atau paniki yaki (Acerodon celebencis). Perlindungan satwa liar mengacu kepada Undang undang No 5 Tahun 1990 tentang Konservasi Sumber Daya Alam Hayati Dan Ekosistemnya. Bab V Tentang Pengawetan Jenis Tumbuhan Dan Satwa, Pasal 21 pada butir 1 setiap orang dilarang untuk : mengambil, menebang, memiliki, merusak, memusnahkan, memelihara, mengangkut, dan memperniagakan tumbuhan yang dilindungi atau bagianbagiannya dalam keadaan hidup atau mati. Jenis satwa yang dilindungi hanya boleh dimanfaatkan untuk keperluan penelitian, ilmu pengetahuan, dan atau penyelamatan jenis tumbuhan dan satwa yang bersangkutan sesuai pasal 22 pada butir 1. Status satwa liar juga mengacu pada Peraturan Menteri Lingkungan Hidup Dan Kehutanan Nomor P.92/MENLHK/SETJEN/KUM.1/8/2018

Tentang Perubahan Atas Peraturan Menteri Lingkungan Hidup Dan Kehutanan Nomor P.20/MENLHK/SETJEN/KUM.1/6/2018

Tentang Jenis Tumbuhan Dan Satwa Yang Dilindungi.

Berikut status konservasi dari 8 jenis daging satwa yang diperdagangkan untuk konsumsi di Sulawesi Utara yang termasuk dalam Permen Lingkungan Hidup dan Kehutanan No 92 Tahun 2018 dan CITES (Convention on International Trade in Endangered Species of Wild Fauna and Flora) yaitu sebagai berikut:

Tabel 4. Status konservasi satwa liar yang diperdagangkan di Sulawesi Utara

\begin{tabular}{|c|c|c|c|c|c|}
\hline \multirow[b]{2}{*}{ No } & \multirow[b]{2}{*}{ Nama Satwa } & \multirow[b]{2}{*}{ Latin } & \multicolumn{2}{|c|}{ Status Konservasi } & \multirow[b]{2}{*}{ keterangan } \\
\hline & & & $\begin{array}{l}\text { Permen No. } \\
92 \text { thn } 2018\end{array}$ & CITES & \\
\hline 1 & Babi Hutan & Sus scrofa & - & - & $\begin{array}{l}\text { Tidak } \\
\text { dilindungi }\end{array}$ \\
\hline 2 & Anjing & Canis lufus & - & - & $\begin{array}{l}\text { Tidak } \\
\text { dilindungi }\end{array}$ \\
\hline 3 & Kelelawar hitam & Pteropus electo & & $\begin{array}{l}\text { Appendiks } \\
\text { II }\end{array}$ & \\
\hline 4 & $\begin{array}{l}\text { Kelelawar } \\
\text { pirang/Paniki Yaki }\end{array}$ & Acerodon celebencis & & $\begin{array}{l}\text { Appendiks } \\
\text { II }\end{array}$ & \\
\hline 5 & Kucing & Felis catus & - & - & $\begin{array}{l}\text { Tidak } \\
\text { dilindungi }\end{array}$ \\
\hline 6 & Ular Phyton & Python reticulatus & - & - & $\begin{array}{l}\text { Tidak } \\
\text { dilindungi }\end{array}$ \\
\hline 7 & Biawak/Soa soa & Varanus salvator & - & - & $\begin{array}{l}\text { Tidak } \\
\text { dilindungi }\end{array}$ \\
\hline 8 & Tikus & Rattus norvegicus & - & - & $\begin{array}{l}\text { Tidak } \\
\text { dilindungi }\end{array}$ \\
\hline
\end{tabular}

Berdasarkan hasil pada Tabel 4 di atas memperlihatkan bahwa hanya kelelawar yang masuk dalam lampiran Appendiks II. Apendiks II adalah daftar spesies yang tidak terancam kepunahan, tetapi mungkin terancam punah bila perdagangan terus berlanjut tanpa adanya pengaturan (CITES, 2017). Sedangkan 6 jenis satwa lainnya termasuk ke dalam satwa yang tidak dilindungi. Jenis satwa yang masuk dalam daftar CITES masih sedikit, Sebagian besar jenis satwa masih belum terdaftar dalam Appendiks CITES dan tidak memiliki data 
yang cukup ataupun tidak dievaluasi. Hal ini terkait masih kurangnya penelitian mengenai satwa yang mengakibatkan terbatasnya data mengenai satwa yang ada di alam, sehingga sulit untuk memastikan apakah pemanfaatan satwa telah memenuhi kaidah kelestarian atau mengancam kelestarian satwa di alam.

\section{KESIMPULAN}

1. Terdapat 8 jenis satwa liar yang diperdagangkan di Pasar-pasar tradisional yang tersebar di Kab. Minahasa dan Kota Manado. Serta terdapat 5 jenis daging satwa liar yang diperdagangkan di supermarket-supermarket yang tersebar di Kota Manado. Daging kelelawar (Pteropus electo/Acerodon celebencis) terdapat di kesemua pasar tradisional dan pasar modern/supermarket.

2. Harga daging satwa liar di Supermarket cenderung lebih tinggi bahkan untuk daging kelelawar 3 kali lipat lebih mahal dari harga di Pasar tradisional.

3. Satwa liar yang dimanfaatkan untuk konsumsi terdapat satu jenis endemik Sulawesi yaitu Acerodon celebencis. Hanya kelelawar baik Pteropus electo dan Acerodon celebencis yang masuk dalam lampiran CITES Appendiks II.

\section{DAFTAR PUSTAKA}

CITES. 2017. Daftar Convention On International Trade In Endangered Species Of Wild Fauna And Flora Appendices I, II and III. valid from 4 October 2017

Guy Cowlishaw, Samantha Mendelson and J. Marcus Rowcliffe. 2005. Institute of Zoology, Zoological Society of London, Regents Park, London NW. Journal of Applied Ecology, 42: 460-468.

Gono Semiadi. 2007. Pemanfaatan Satwa Liar Dalam Rangka Konservasi dan Pemenuhan Gizi Masyarakat. Bidang Zoologi, Puslit Biologi-LIPI Cibinong.
Ignasius Mirdat, S.M Kartikawati, Sarma Siahaan. 2019. Fakultas Kehutanan Universitas Tanjungpura. Jurnal Hutan Lestari Vol. 7 (1) : 287 - 295.

Kartikasari D. 2008. Keanekaragaman Jenis dan Nilai Ekonomi Satwa Liar yang Digunakan Sebagai Obat Di Jawa Tengah. Program Pascasarjana Institut Pertanian Bogor.

Lee R.J., Gorog A.J., Dwiyahreni A., Siwu S., Riley J., Alexander H., Ramono W. 2005. Wildlife Trade and Implications for Law Enforcement in Indonesia: A Case Study From North Sulawesi. Biol. Conserv. 123, 477-488.

Liana, Maulany R, Makkarennu, Baharuddin. 2019. Study of Fruit Bat Trade and Percepstion of Communities About Fruit Bat Consumption inNorth Sulawesi. Pascasarjana Ilmu Kehutanan Universitas Hasanuddin Makassar

Mildenstein, T., Tanshi, I., Racey.,P.A. 2016. Exploitation of Bats for Bushmeat and Medicine. DOI 10.1007/978-3-319-252209_12

Saroyo. 2011. Konsumsi Mamalia, Burung, dan Reptil Liar Pada Masyarakat Sulawesi Utara dan Aspek Konservasinya. Jurnal Bioslogos, agustus 2011, vol. 1 nomor 1.

Sheherazade, Tsang .M. 2015. Quantifying the Bat Bushmeat Trade in North Sulawesi, Indonesia with Suggestion for Conservation Action. Global Ecology and Conservation.

Sinaga Pariaman. 2004. Pasar Modern VS Pasar Tradisional. Jakarta: Kementerian Koperasi dan UKM.

Taogan S., Kainde R.P., Tasirin J.S. 2020. Perdagangan Jenis Satwa Liar Di Pasar Langowan Kab. Minahasa Sulawesi Utara. Program Study Ilmu Kehutanan, Jurusan Budidaya Pertanian Fakultas Pertanian Universitas Sam Ratulangi Manado. 